\title{
COVID-19 pandemic and nursing week: analysis from software Iramuteq
}

\author{
Pandemia de Covid-19 e a semana de enfermagem: análise a partir do software Iramuteq \\ COVID-19 pandemia y semana de enfermería: análisis del software Iramuteq
}

\section{Samira Silva Santos Soares' ORCID: 0000-0001-9133-7044}

Norma Valéria Dantas de Oliveira Souza' ORCID: 0000-0002-2936-3468

Eloá Carneiro Carvalho' ORCID: 0000-0002-1099-370X

Ana Beatriz Azevedo Queiroz" ORCID: 0000-0003-2447-6137

Carolina Cabral Pereira da Costa' ORCID: 0000-0002-0365-7580

Jaqueline da Silva Soares Souto" ORCID: 0000-0003-2069-5260

'Universidade Estadual do Rio de Janeiro. Rio de Janeiro, Rio de Janeiro, Brazil.

"Universidade Federal do Rio de Janeiro. Rio de Janeiro, Rio de Janeiro, Brazil.

How to cite this article: Soares SSS, Souza NVDO, Carvalho EC, Queiroz ABA, Costa CCP, Souto JSS. COVID-19 pandemic and nursing week: analysis from software Iramuteq. Rev Bras Enferm. 2022;75(Suppl 1):e20200690. https://doi.org/10.1590/0034-7167-2020-0690

Corresponding author:

Samira Silva Santos Soares E-mail: samira_opg@hotmail.com

EDITOR IN CHIEF: Dulce Barbosa ASSOCIATE EDITOR: Elisabete Salvador

\section{ABSTRACT}

Objective: to analyze the themes of publications on the Federal Council of Nursing (Cofen) website during Nursing Week 2020. Method: documentary, qualitative research, whose data sources were publications on the Cofen website from May 12 to 20, 2020. Data were processed by software IRAMUTEQ; ${ }^{\circ}$ through the Descending Hierarchical Classification and analyzed under the historical materialism framework. Results: thirty publications were analyzed, giving rise to five classes. Final considerations: the themes published in the period investigated pointed to the grief experienced by the category, due to the death of its members, and the fight for better working conditions. Overcoming the pandemic involves recognizing science and the Unified Health System, protecting nursing workers' health and fighting misinformation and fake news.

Descriptors: Pandemics; Nursing; Social Media; News; Software.

\section{RESUMO}

Objetivo: analisar os temas das publicações do sítio eletrônico do Conselho Federal de Enfermagem (Cofen) durante o período que compreende a Semana de Enfermagem 2020. Método: pesquisa documental, qualitativa, cujas fontes de dados foram publicações do sítio eletrônico do Cofen durante o período de 12 a 20 de maio de 2020 . O corpus textual foi submetido ao software IRAMUTEQ ${ }^{\circ}$, os dados processados por meio da Classificação Hierárquica Descendente e analisados sob o referencial do materialismo histórico. Resultados: foram analisadas 30 publicações, dando origem a cinco classes. Considerações finais: os temas publicados no período investigado apontavam o luto vivenciado pela categoria, em virtude da morte de seus integrantes, e o enfrentamento por melhores condições de trabalho. A superação da pandemia envolve o reconhecimento da ciência e do Sistema Único de Saúde, a proteção à saúde dos trabalhadores de enfermagem e o combate à desinformação e às fake news.

Descritores: Pandemias; Enfermagem; Mídias Sociais; Notícias; Software.

\section{RESUMEN}

Objetivo: analizar los temas de las publicaciones en el sitio web del Consejo Federal de Enfermería (Cofen) durante la Semana de Enfermería 2020. Método: investigación documental, cualitativa, cuyas fuentes fueron de datos fueron publicaciones en el sitio web del Consejo Federal de Enfermería durante el período del 12 al 20 de mayo de 2020. El corpus textual fue sometido al software IRAMUTEQ ', los datos procesados a través de la Clasificación Jerárquica Descendente y analizados en el marco del materialismo histórico. Resultados: se analizaron 30 publicaciones, dando lugar a cinco clases Consideraciones finales: Ios temas publicados en el periodo investigado apuntaban al duelo vivido por la categoría, por la muerte de sus integrantes, y el por Consejo Federal de Enfermería apuntaron al dolor que vive la categoría, por la muerte de sus integrantes, y el enfrentamiento por mejores condiciones laborales. Superar la pandemia implica reconocer la ciencia y el Sistema Único de Salud, proteger la salud de los trabajadores de enfermería y combatir la desinformación y las noticias falsas. Descriptores: Pandemias; Enfermería; Medios de Comunicación Sociales; Noticias; Software. 


\section{INTRODUCTION}

For nursing professionals, May has a special meaning because, on the $12^{\text {th }}$, the International Nurses Day is celebrated, and, on the $20^{\text {th }}$, the Brazilian National Day of Nursing Technicians and Assistants is celebrated. These dates were not randomly chosen, they represent, respectively, the birth of Florence Nightingale, precursor of modern nursing, and the death of Anna Nery, a nurse who is a historical reference in the Brazilian context, respectively ${ }^{(1)}$.

It should also be noted that, in 1940, Lais Netto dos Reys, Director of the Anna Nery School of Nursing at the time, suggested that from May 12 to 20, Nurses Week should be celebrated, using, in 1958, the name Brazilian Nursing Week, being officially recognized in 1960 through Decree 48.202/60, signed by President Juscelino Kubitschek de Oliveira ${ }^{(1)}$. Since then, the Brazilian Nursing Week (SBEn - Semana Brasileira de Enfermagem) takes place and has as an important protagonist the Brazilian Nursing Association (ABEn - Associação Brasileira de Enfermagem), which, through its board and affiliated members, organizes, articulates and socializes the scientific commemorations of such period ${ }^{(1)}$.

In 2020, the $81^{\text {st }}$ SBEn took place, with the theme "Quality in Nursing and Health in the Defense of SUS [Unified Health System - Sistema Único de Saúde]". For the first time in the history of SBEn, the programming and actions related to the event took place online, with the right to lives - videos made live by social networks and/or digital platforms - and "twitaço" - an alternative form of manifestation, like "panelaços", a protest by banging pots, but performed virtually on Twitter".

This fact occurred due to the COVID-19 pandemic, declared by the World Health Organization (WHO) in March 2020. COVID-19 is a disease that emerged at the end of 2019 in China, caused by a new coronavirus, called SARS-CoV-2 ${ }^{(1-2)}$.

As, until the end of 2020, there was no vaccine or specific treatment for COVID-19 in Brazil, non-pharmacological measures were the only options for fighting this pandemic, being extensively recommended and systematically disseminated. Among them, the increased social distance stands out, a strategy advocated to reduce the rate of infection by the virus ${ }^{(3-4)}$. In this sense, holding events that promote agglomerations has been contraindicated, and these should be suspended, postponed, or, when possible, carried out with the help of virtual technologies. Thus, ABEn and other nursing entities considered it prudent to carry out SBEn virtually, a decision that was readily accepted and adhered to by the professional collective.

It is noteworthy that the year 2020 will be marked as unusual and atypical for humanity, but it can also represent a time of greater material and symbolic recognition for nursing, as, in addition to its relevant and indispensable role in combating COVID-19, this year was defined by WHO as the "Year of the Nurse and the Midwife 2020". This definition is based on the importance that the profession has in promoting health and preventing injuries, as well as contributing to the treatment and rehabilitation of sick people ${ }^{(5)}$. From this perspective, the WHO initiative was in line with the role that nursing has taken on in the fight against the pandemic.

However, it should be stated that, despite these considerations, nursing workers still face, in many places, inadequate working conditions, which results in high physical and mental suffering, illness and death for many professionals. For example, in 2020, more specifically on May 12 of that year, according to the Federal Council of Nursing (Cofen - Conselho Federal de Enfermagem), among Brazilian nursing professionals, there were already more than one hundred deaths and 4,128 were already infected with COVID-19(6-7).

It is noteworthy that, in 2020,44,441 nursing professionals left their work activities and needed to be quarantined after being infected by the new coronavirus ${ }^{(8)}$ and more than 500 died as a result of COVID-19 in that year ${ }^{(9)}$. Many of these regrettable data are linked to the lack or inadequacy of personal protective equipment (PPE), long hours worked, double shifts, under-sizing of personnel, among other situations that damaged these workers' health ${ }^{(6)}$.

This study is justified because it contextualizes valuable issues for the profession, such as the commemorative dates of nursing, the historical landmark of SBEn and the fact that 2020 was chosen as the year to recognize and value nursing worldwide. In addition to this, its importance is also located in the high occurrence of COVID-19 among the Brazilian population, which has even been making professionals ill and claiming the lives of nursing workers, which demands confrontations and challenges for the profession. Furthermore, it is justified as a way of recording and highlighting themes that emerged in a historical moment of great importance for worldwide nursing and, in particular, for Brazilian nursing.

\section{OBJECTIVE}

To analyze the themes of publications on the Federal Council of Nursing (Cofen) website during the Nursing Week 2020.

\section{METHODS}

\section{Ethical aspects}

Since the research did not directly involve human beings and the data were collected in an open-access website, the need for consideration of the study was dispensed with by an Institutional Review Board (IRB).

It is noteworthy, however, that at the end of each article/news published on the researched site, which originates from other sources, copyright was also respected, preserving the proper identification of authorship.

\section{Study design, place of collection and data source}

This is a documentary, qualitative research, whose primary data sources were publications (reports and news) published on Cofen website (www.cofen.gov.br) in the menu "Press", tab "News". The study preparation sought to meet the steps recommended by the Consolidated Criteria for Reporting a Qualitative Survey (COREQ) ${ }^{(10-11)}$.

It is considered that the Cofen Portal, in addition to serving as an important source of consultation to equip professionals in the category, offers transparency regarding the actions and 
deliberations of the system itself, allowing nursing members to understand what managers have been doing to from the power of representation entrusted to them ${ }^{(12)}$.

\section{Theoretical-methodological framework}

This study is based on historical materialism, whose choice is supported by the fact of investigating the world of nursing work and the contradictions that permeate this work activity ${ }^{(13)}$. The historical materialist conception even ponders that the health-disease process is socially defined and marked by social transformations in a given historical period, generating changes in health both in the aspect of individuality of the being and in the collective configuration and structure of the health system ${ }^{(13)}$. Thus, the theoretical framework of this study allows for an understanding of what has been happening to society and its consequences for the health sector and for the work of nursing.

Furthermore, the theoretical constructs of historical materialism present the law of quantity for quality, which is also relevant to the context of interest of this study. Therefore, it is understood that the more one discusses and worries about a given phenomenon, the more likely it is to transform it ${ }^{(13)}$. In this sense, it is intended to deepen the discussion on the current configuration of nursing work, in which the precariousness of their working conditions, illness of the workforce and its negative consequences for the service offered to the population are present, thus causing strangeness and tensions with the aim of transforming this unusual and incongruous reality into a qualitatively better scenario for the professional collective.

From this angle, the contradiction that the nursing work is indispensable for society stands out, in particular, but it has little recognition and often inadequate working conditions. Above all, in times of pandemic, when it is necessary to keep the workforce healthy, there is a shortage of PPE and long working hours. In this sense, it is understood that the present study emphasizes contradictions, thus transforming them through quantitatively and qualitatively planned actions and strategies.

\section{Data collection and organization}

Data (publications, news/reports) were collected and cataloged during the Nursing Week 2020, i.e., considering May 12 - International Nurses Day - and, as the final date, May 20 - Brazilian National Day of Nursing Technicians and Assistants.

\section{Data analysis}

For content lexical analysis, the free software called Interface de $R$ pour les Analyses Multidimensionnelles de Textes et de Questionnaires (IRAMUTEQ), version 0.7, alpha 2 was used. IRAMUTEQ is a free software that performs the lexical analysis of words. By "lexicon", we mean the use of a word in a given context. An advantage of using the IRAMUTEQ ${ }^{\circ}$ is that it allows the application of apply statistical calculations on qualitative data, thus increasing the rigor and reliability of qualitative analysis ${ }^{(14)}$.

The following steps were considered for submitting the textual material to IRAMUTEQ:
1. Organization and preparation of all data, with the grouping of all publications in a single file called textual corpus. As it was not the objective of analysis to identify authors' names or references used in publications, this information was suppressed. The title of the publications and their respective summaries were also removed, leaving, therefore, after each command line, only the content itself of the publications. It is noteworthy that "corpus" is the set of all the material to be analyzed with the software aid, which, in this study, were the publications. In turn, each publication was renamed Text. Text segments (TS) are the environments of words, the main textual analysis units of this type of software ${ }^{(15)}$. Command lines, also known as "asterisk lines" or metadata, are responsible for indicating the separation of one text and another ${ }^{(15)}$. Each publication (text) was separated by a command line composed of specific codes for software recognition. The command lines started with four asterisks, $\left({ }^{* * *}\right)$, space, plus an asterisk $\left(^{*}\right)$ with the publication identification (pub_1 to pub_30, according to the order of publications found), as in the example: ${ }^{* * * *}$ pub_01.

2. For a general perception of the themes of the publications, all were read.

3. Data processing through IRAMUTEQ ${ }^{\circ}$ and the Descending Hierarchical Classification (DHC).

The objective of DHC is to obtain classes, each of these classes being composed of a vocabulary/lexicon, simultaneously, analogous to each other and distinct from the vocabulary of the other classes, allowing analysis of TS and calculating distances and proximities from chi-square tests $\left(\mathrm{chi}^{2}\right)^{(15)}$.

From the $\mathrm{DHC}$, the software organizes the texts in a dendrogram (diagrammatic representation) which illustrates the approximations and distances between classes ${ }^{(15)}$. With the evaluation of the dendrogram, the lexicons, the TS and the outstanding variable in the class (in this case, the identification of the publication), it is possible to return to the literature and the theoretical framework to make inferences and interpretations of the material analyzed, including naming each class based on the lexical content obtained through DHC. In other words, the software acts as a tool to facilitate the organization of data, but the researchers are responsible for properly carrying out the analysis based on the proposed framework.

In the presentation of results, at the end of the TS, there will be the identification of the publication (news) through the term "not", followed by the number that indicates the order of identification of the publication. It is also worth mentioning that TS (considered excerpts from publications) were copied in full, without interference by the authors.

\section{RESULTS}

The corpus of analysis consisted of 30 publications that, when processed by IRAMUTEQ ${ }^{\circ}$, identified 529 TS and took advantage of this set, 399 , which represents a total of $75.43 \%$ of the researched content.

Through DHC, five classes were identified. Figure 1 shows a dendrogram in vertical mode, in which the active forms contained 
in the TS associated with each class are indicated. Thus, in this figure, it is possible to observe that the first partition of the corpus gave rise to Class 5 (represented by $17.5 \%$ of the material - 70TS), the second partition gave rise to Class 1 (with 18.3\% - 73TS), the third partition gave rise to Class 2 (17.5\% - 70 TS) and, finally, the fourth partition separated Class 3 (with $18.6 \%$ - 74 TS) and 4 (with $28.1 \%$ - 112 TS). Class 4 , therefore, is the one with the greatest representation in the corpus, as it incorporates most of the TS. From this division, DHC ceased the divisions into classes, as the five classes proved to be stable, i.e., composed of TS units with similar vocabulary.

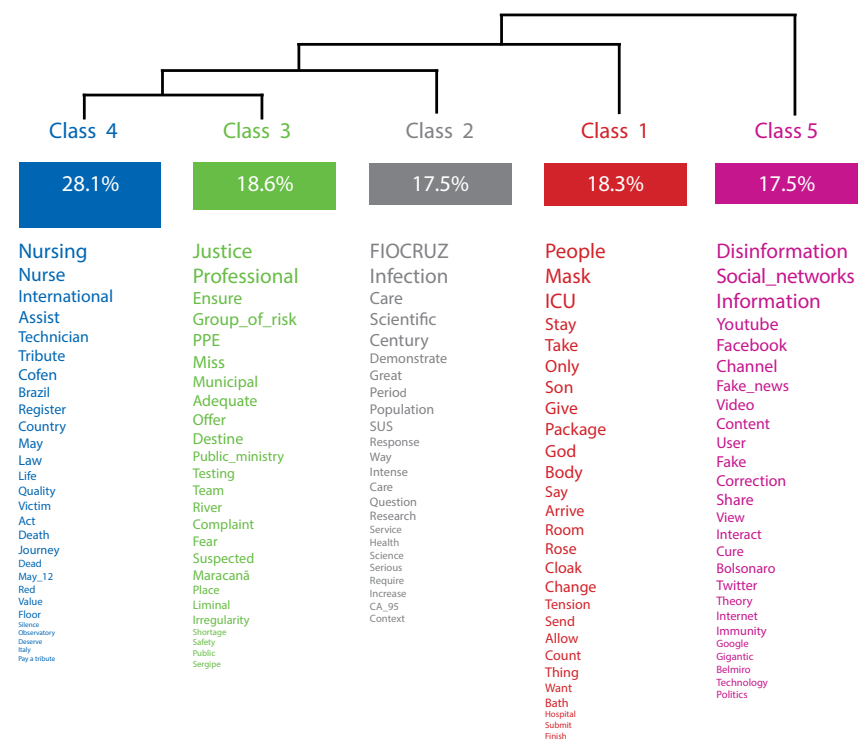

Figure 1 - Descending Hierarchical Classification dendrogram

Class presentation will follow the order in which they originated $(5,1,2,3$ and 4). From the five identified classes, 4 major themes emerged. The first, represented by Class 5, was called "COVID-19 pandemic and fight against fake news" for dealing with the role of nursing with other partner companies, in order to combat fake news amidst the COVID-19 pandemic.

"Healthcare professionals publish a letter asking for the end of the circulation offakenews. This letter was drawn up by people from Brazil and 16 other countries. Researcher states that, among Brazilians, disinformation has a strong political motivation"(16). (Not 12)

The second theme, represented by Class 1, was called "Nursing professionals on the front lines of the fight against the pandemic located in a context of precariousness". This class points out changes in the routine of professionals who work in direct assistance to people with COVID-19, workers' perceptions, as well as their concerns and fears.

"Ilost count of how many bodies I packed, reports a nursing technician at one of the most overcrowded hospitals in Manaus. "I can't sleep well. I dream that I am making a patient package ${ }^{\text {(17). }}$. (Not 16)

"Afraid of infecting family members, many of these professionals have isolated themselves and have lived, in recent weeks, a mixture of anguish and loneliness"(18). (Not 20)
The third theme, represented by Class 2, was called "In defense of science and SUS: Constitutional Amendment 95 revoked". This class highlights the importance of scientific knowledge, research, researchers, public institutions of education, research and technology development and SUS. At the same time, it denounces the lack of investment in the health and education sectors.

\begin{abstract}
"The pandemic demonstrates, alarmingly for the ideologues of limitless individualism, that health cannot be treated without the dimension of collectivity. We defend with redoubled force the repeal of Constitutional Amendment 95, which froze SUS funding for 20 years" ${ }^{\prime \prime 19}$. (Not 27)

"It's time for the Brazilian National Congress to finally discuss the national salary floor and unlock the 30-hour journey for nursing. The great heroes of care are also human beings, who have the same needs and are subject to the same risk factors as the

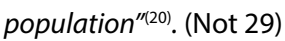

Finally, the last theme was entitled "The nursing we have and the nursing we want". This theme is treated through two classes, i.e., Class 3, which was called "Judicialization of health and the rights of nursing workers", and Class 4, marked as "Tributes: in life or death?".

Class 3 points out the struggles waged by nursing in search of better working conditions during the pandemic, in addition to the risks and threats to these workers' health. In this class, the contradictions that permeate the world of work in health and nursing were very evident.

"The justice forced the city of Rio de Janeiro to adopt preventive measures in two of the biggest emergencies in Rio, while the Public Ministry of Rio de Janeiro opened an inquiry yesterday, after a video showing nursing professionals lying on mattresses in the corridor of the Maracana field hospital inaugurated less than a week ago"(21). (Not 17)

"The entity even filed public civil actions to ensure the removal of professionals from SUS and the private network who were in a risk group and dealt directly with infected patients. Even those who have all the proper apparatus of personal protective equipment have lived a routine of anguish"(28). (Not 20)

Class 4, in turn, shows that, in the Nursing Week 2020, the "traditional" tributes, i.e., the scientific, cultural and social events that promote fraternization among nursing professionals, gave way to a movement of mourning and fighting. Considering the pandemic, the tributes that prevailed were in reverence/mention to the victims caused by COVID-19 among the professional category. The concern with the situation of Brazilian nursing in the context of the pandemic was also evident.

"At the end of the afternoon of May 12, 100 nursing professionals gathered outside the Museum of the Republic, in Brasilia, to honor the 108 colleagues who have already lost their lives on the front line of combating the coronavirus ${ }^{\prime \prime(6)}$. (Not 9)

"The situation in Brazil is critical. The nursing observatory created by Cofen to monitor the evolution of the pandemic among nursing professionals has already registered more than 13 thousand cases and 100 deaths associated with COVID-19"(22). (Not 1) 
From the DHC, it was also possible to identify the prominent publications in each class, and Table 1 presents the results, considering those that showed greater significance $(p<0.0001)$ in the chi-square $\left(\mathrm{chi}^{2}\right)$ analysis.

Table 1 - Prominent news highlighted in each class $(p<0.0001)$, Rio de Janeiro, Rio de Janeiro, Brazil, 2020 $(\mathrm{n}=30)$

\begin{tabular}{|c|c|}
\hline Class 5 & ${ }^{*} \mathrm{Chi}^{2}$ \\
\hline $\begin{array}{l}\text { "Fake news channels have more reach than the official ones on COVID-19"(23) } \\
\text { "Against lies, healthcare professionals demand action from the technology giants"(24) } \\
\text { "Cofen adheres to the Charter of Healthcare professionals against fake news"(16) }\end{array}$ & $\begin{array}{l}86.8 \\
62.2 \\
42.0\end{array}$ \\
\hline Class 1 & ${ }^{*} \mathrm{Chi}^{2}$ \\
\hline $\begin{array}{l}\text { "I lost count of how many bodies I packed," reports a nursing technician"(17). } \\
\text { "A nurse recovered from COVID-19 in Rondônia becomes an example of overcoming difficulties"(25) }\end{array}$ & $\begin{array}{l}97.1 \\
16.8\end{array}$ \\
\hline Class 2 & ${ }^{*} \mathrm{Chi}^{2}$ \\
\hline "Fiocruz President emphasizes the importance of science in the fight against COVID-19"(26) & 58.2 \\
\hline Class 3 & ${ }^{*} \mathrm{Chi}^{2}$ \\
\hline $\begin{array}{l}\text { "Why do hospitals in RJ have more deaths among nurses in the country?"(21) } \\
\text { "Justice grants testing to symptomatic nursing professionals in Sergipe"(27) } \\
\text { "Cofen repudiates discrimination against nursing professionals in Rio"(28) }\end{array}$ & $\begin{array}{l}29.7 \\
22.2 \\
16.7\end{array}$ \\
\hline Class 4 & ${ }^{*} \mathrm{Chi}^{2}$ \\
\hline "Nursing performs a historic act in honor of those killed by COVID-19"(6) & 23.3 \\
\hline
\end{tabular}

According to Cofen, nursing professionals have already suffered attacks, due to untrue information about COVID-19 ${ }^{(18)}$. This worrying context led Cofen to join the international campaign against fake news about the new coronavirus, as it considers that they can cause negative impacts on the health of the population and understands that there is a need for actions in the midst of the crisis to be guided by scientific evidence. The campaign demands that social media platforms take stricter conduct to remedy cases of fake news related to COVID-19, for example, by correcting information that is proven to be false by notifying users who have seen and interacted with disinformation in health ${ }^{(31)}$.

Combating fake news requires social mobilization and a joint effort by society, as they are often linked to a proposal of a partisan political nature. In this sense, it should be noted that, in Brazil, since the beginning of the pandemic, President Jair Messias Bolsonaro and many of his co-religionists have minimized the severity of the health crisis and encouraged the population to adopt measures that diverge from those

\section{DISCUSSION}

Healthcare professionals from around the world are engaged in the fight against the new coronavirus. But these professionals are also being summoned and/or impelled to deal with another evil: misinformation. In this context, the term "infodemic" circulates, which can be conceptualized as the spread of misinformation or inaccurate information about the pandemic ${ }^{(29)}$. The greater the misinformation, the greater the risk of increasing morbidity and mortality from COVID-19, as the population is confused, not knowing who or what to believe, even distrusting public health institutions, science and researchers ${ }^{(29)}$.

The fact is that, although the literature on topics involving the COVID-19 pandemic is still scarce, numerous untruths are being published in chat apps, on social media platforms and even in the media. These fake news, called fake news, circulate as truths that are quickly popularized and have a social impact $^{(29-30)}$. However, this emerges as a contradiction, since correct information is relevant to contribute to the prevention of the spread of the virus.

In an attempt to combat fake news, the WHO and the Ministry of Health published, on their website, a channel to inform the population about such news. These institutions also made available a WhatsApp number, so that people can ask questions about what is actually true. Recognizing fake news and its potential to aggravate the situation of the current health crisis is essential, as they promote misinformation at a time when society needs access to accurate, clear and reliable information ${ }^{(29-30)}$. directed by scientific institutions, such as supporting the use of drugs that are not proven and effective for the treatment of disease caused by the new coronavirus ${ }^{(32-33)}$. In this sense, it is understood that this is a distorted and misleading use of information, even promoted by non-traditional media, in order to confuse the population and politically minimize a serious public health situation.

Thus, to overcome this health crisis, it is necessary that nursing professionals take over not only the front line and direct patient care, but, above all, that they denounce fake news and use health education to bring clarification to the Brazilian population. The challenge is to present the results of research and scientific evidence to the broad public, in an easily understood language, so that fake news does not continue to further threaten the lives of so many Brazilians and citizens around the world ${ }^{(16,29-30)}$.

Regarding the work of nursing professionals in the front line of combating coronavirus, it is important to highlight that, even before the WHO decreed the pandemic resulting from COVID-19, reports from nursing professionals were already circulating in the media and social networks. Cofen, on March 12, 2020, for example, reposted the report of an Italian nurse about work and the new routine in the midst of coronavirus. The statement moved internet users, as the photo of the nurse showed the marks on her face resulting from the use of PPE and the statement mentioned concerns and fear in relation to what had been experienced ${ }^{(33)}$.

With the passing of days and the growing number of cases of COVID-19 in Brazil, the leading role of Brazilian nursing was also in evidence. Represented by 2,315,421 professionals ${ }^{(34)}$, including assistants, technicians and nurses, therefore, the largest workforce 
in the health area, the category - which is generally little recognized and little valued, despite being essential to the process of work of public and private health services - has gained relative notoriety. After all, if, on the one hand, the reality imposed by the pandemic made the media highlight the importance of the role of nursing, on the other hand, the situations of illness and death among professionals in the category and the evidence on the high occupational risks and the inadequate working conditions they were/are exposed in their work environment alerted and even moved the population ${ }^{(35)}$.

It is worth mentioning that nursing works in several health services, dealing with the most different care situations, from primary care to high complexity ${ }^{(36)}$. Nursing professionals, more specifically nurses, even work beyond the care field, as they are involved in activities related to management, teaching and research, among other fronts ${ }^{(36)}$.

However, nursing is a professional category that, despite being "the backbone of any health system"(37), is also responsible for fighting in defense of patients and for complying with constitutional precepts regarding the rights they protect human health and dignity, has suffered for years with the devaluation of its workforce ${ }^{(38)}$.

In this sense, it should be noted that, for Marx ${ }^{(39)}$, in the capitalist mode of production, in which labor power is a commodity, labor capacity is nothing if it is not sold. If on the one hand the work is intended to enable human beings to produce and reproduce socially, aiming to produce the vital, material and symbolic means necessary for human survival, on the other hand, it can also become its opposite, a mere means of subsistence whose main purpose is to value capital ${ }^{(40)}$.

It is essential to understand that nursing is a specialized profession that aims to contribute to the well-being and health of people through the exercise of their profession, but its workers operate in a labor market whose focus is on capital and which seeks at all times to exploit the workforce. Thus, capital cares little or nothing about the psychophysical suffering of this professional collective or the repercussions of the illness of the nursing team for the reproduction of life in society, what really matters is the productivity and profit extracted from exploitation unrestrained workers.

Low pay, predominance of women in the profession, the social and technical division of labor, lack of legislation that defines the wage floor and working hours of the category, the existence of a reserve army of professionals and inadequate working conditions are aspects that put these workers' health at risk and generate fear of illness, workplace violence, evasion from the profession, among other negative consequences. Furthermore, they show the low social and professional recognition that Brazilian society has in relation to the work of nursing professionals ${ }^{(38)}$.

Ratifying, having an eminently female workforce in nursing explains, in a way, its incipient socioeconomic valuation, since professions with a predominance of women, in an androcentric and sexist world, suffer from little material recognition and social valuation. Moreover, the division of labor (social and technical) results in fragmentation, tensions and extremely demarcated power relations among the members that make up this professional category ${ }^{(41-42)}$.
Thus, this situation acts in favor of capital, as it makes it possible to perpetuate the political, social and economic interests characteristic of the capitalist model, as it blunts workers in their reflective and critical capacity about the real reasons that exploit and exploit the nursing workforce, contributing to the maintenance of relations of domination/subordination. It should be noted that this intra-class fragmentation and tension has hindered the organization of its agents in the collective struggle for better working conditions and in dealing with the precariousness that has been plaguing the profession ${ }^{(41-42)}$.

Furthermore, in a context of precariousness of nursing work, as an effect of capitalism and the neoliberal model, there is an increase in unemployment, outsourcing, loss of rights in the social and labor sphere, the multiplicity of employment relationships and the submission of the category to unworthy working conditions as ways to keep their jobs and guarantee their livelihood ${ }^{(43)}$.

Neoliberalism is an economic policy of deregulation of economic and financial relations by the State, which encourages the indiscriminate opening of the national market to the international one, in addition to advocating the minimum State, streamlining the public machine and having no accountability for social welfare. In this sense, it undoubtedly impacts the economic, political, cultural and psycho-emotional values of citizens, transforming life in society and labor relations ${ }^{(44-45)}$. From this angle, the neoliberal ideology has been producing changes that create obstacles to safe and quality healthcare, since there is disinvestment in infrastructure, workforce and material resources to develop care in health services ${ }^{(45)}$.

These situations are even more evident in the current context of the COVID-19 pandemic, a time when emergency calls and temporary contracts via social organizations and the adoption of provisional measures (PM) are observed - such as PM $927 / 2020$, which disregards the scenario of nursing work, which, with undersized teams and overloaded with work, may, during the pandemic, increase the working day by up to 24 hours and reduce rest time to 12 hours $^{(43)}$.

Coincidentally or not, in the year entitled by WHO as "International Year of the Nurse and Midwife", the challenges of the category loom large and, if a set of measures and policies to protect these workers are not urgently implemented, the outcomes of the pandemic, especially in health physical and mental health of such professionals can be devastating. In this sense, Brazilian nursing calls not only for the recognition of its work and its social importance, but for better working conditions.

The WHO highlights that governments need to massively invest in nursing education, job creation and promoting the leadership of these professionals to ensure there is a sufficient nursing workforce with the right skills to strengthen health systems, that need to be effective, equitable and sustainable ${ }^{(46)}$. In the Brazilian case, fortifying SUS involves, among other aspects, revoking Constitutional Amendment (CA) 95.

CA 95 was approved in 2016, during the government of President Michel Temer. This 20-year amendment not only froze public spending, but also reduced social spending as a percentage per capita. That is, even if the population and the economy grow, the funds made available to the health and education sectors will be the same as in 2017 , corrected only for inflation, as measured by 
the Broad National Consumer Price Index (IPCA - Índice Nacional de Preços ao Consumidor Amplo) ${ }^{(47)}$.

In this context, in the field of education, there has been, in recent years, a disinvestment in research, a growing number of cuts in scholarships inside and outside the country, the scrapping of public universities, among other problems. In the health sector, the disinvestment of SUS, the lack of equipment and supplies, the lack of public tenders and labor, the salary gap of professionals and the deterioration of the physical structures of the care units due to lack of maintenance are mentioned. In other words, CA 95 made room for the scrapping of areas fundamental to the development of society and for the elimination of its universal and equitable character, since it mainly met the needs of the most vulnerable population, extinguishing their possibility of a life worthy ${ }^{(47)}$.

In reality, CA 95 breaks a social pact that was signed with the promulgation of the Federal Constitution of Brazil in 1988, as it weakens and limits investments in social policies, weakening the entire Brazilian social protection network. It is the literal dismantling of public and social policies in Brazil, representing a disruption in the growth of public investments in education and health.

Unfortunately, it was in the midst of the pandemic and noting that the lack of research laboratories in large public institutions limited carrying out tests to detect SARS-CoV-2 and that SUS was not able to meet the demands of the crisis and recorded a lack of beds, professionals and PPE that the weaknesses of the public health and education sectors were in evidence ${ }^{(48-50)}$. Thus, it is necessary that civil and academic society demand, in defense of science and SUS, responsibility and commitment of government officials with the Federal Constitution and with Brazilian society, protesting in favor of the repeal of CA 95, to avoid one of the greatest $21^{\text {st }}$ century health tragedies ${ }^{(51)}$.

After all, the Federal Constitution of Brazil, in its article 196, states that "health is everyone's right and the State's duty". Therefore, this fundamental right must be guaranteed to all Brazilian citizens, with a view to ensuring the principle of dignity, preservation and enhancement of human life ${ }^{(52)}$. The problem faced today in SUS, a primary consequence of the scrapping and no funding of health, reflects on two important points: in the health of the assisted population, who fall ill without the prospect of effective treatment conditions; in workers' health, responsible for assisting the population, who are also sick, psychologically and physically, due to the working conditions to which they are subjected ${ }^{(48,53)}$.

As a result of this reality, there is the judicialization of health, a means that the population and healthcare professionals find so that their rights are fulfilled ${ }^{(54)}$. During the pandemic, it is possible that cases of judicialization increase, due to the population's dissatisfaction with the health services that are on the verge of collapse and of healthcare professionals with the unsatisfactory working conditions of the services where they work.

It is necessary to include in the debate the consequences that court decisions produce in the services provided by SUS and in nursing work ${ }^{(55)}$. For example, even after the Union of Nurses of Rio de Janeiro obtained, through an injunction, permission for professionals in the group at risk for COVID-19 to be released from face-to-face work and could work in a home office regime during the pandemic, the First Region Regional Labor Court revoked this decision and decided that nurses, even though members of risk groups, should work, so that there was no harm to healthcare services.

With this in mind, some Bills have also been designed to offer more security to professionals and adequate working conditions. Noteworthy is Bill 1.242/2020, which establishes that "the organs and entities of SUS, as well as private service providers, adopt, as a priority, measures to ensure the acquisition and distribution of personal protective equipment for all healthcare workers for the duration of the state of public calamity recognized by Legislative Decree 6 of $2020^{\prime \prime(56)}$.

Amidst the pandemic, the Public Ministry of Labor of the State of Rio de Janeiro also needed to take a stand and opened an inquiry to investigate complaints of poor working conditions at Maracanã field hospital after the socialization of a video showing nurses and nursing technicians sleeping on mattresses in the floor. It is emphasized, therefore, that it is essential and urgent, more than the recognition and symbolic valuation of the profession, to guarantee conditions of protection and safety for these workers, whether through the judicialization of health or from the approval of new or old bills - as the one that regulates the 30-hour workday for nursing, the payment of unhealthy conditions at the maximum level to professionals involved in the fight against the pandemic, the national wage floor, among others.

Finally, since 2020 is considered the year of nursing and Florence Nightingale's bicentennial is commemorated, it would be pertinent that this year's Nursing Week was full of tributes to the profession, and many actually happened. However, the COVID-19 pandemic gave another perspective to these solemnities. The festivities gave way to mourning, due to the deaths of more than 100 nursing professionals victimized by COVID-19 until May 12, 2020. It also highlighted the fight for better working conditions, especially for those who are in direct care of suspected or confirmed patients with COVID-19(6).

On Nurses Day, in a historic event, 100 nursing professionals gathered in the external area of the Museum of the Republic, in Brasília, to honor colleagues who died as a result of contamination by the coronavirus. The act was organized by the Union of Nurses of the Federal District (SindEnfermeiro-FD (Sindicato dos Enfermeiros do Distrito Federal)), by the Union of Nursing Assistants and Technicians of FD (Sindate-FD (Sindicato dos Auxiliares e Técnicos em Enfermagem)), by Coren-FD and by Cofen itself, respecting social distancing measures and use masks and the silence of the professionals in the act caused a global commotion, being socialized by the media of several countries ${ }^{(6)}$.

It is necessary to improve the working conditions of the category, this is an unquestionable truth. It is known, for example, that PPE is essential for the protection of workers, but they are also scarce, and it is sometimes necessary to reuse them and/or limit trips to the bathroom or breaks at work, to avoid removal of equipment, contamination and the need to dispose of these inputs ${ }^{(48,50)}$. This situation, in addition to the potential to cause physical illness, also implies fear of contamination and generates psychological distress, due to the feeling of devaluation and disregard for the organization of work.

Regarding the infrastructure of health services, data from the Nursing Profile Survey in Brazil (Pesquisa Perfil da Enfermagem no Brasil) revealed, even before the pandemic, that more than half of the interviewed professionals did not have adequate physical 
structure to develop the work process and also to rest during the work shift. Moreover, only a little more than $40 \%$ of nursing professionals are assisted, when they fall ill, by the institution in which they work, i.e., almost half of the team, although dealing directly with the care and health of people, has no institutional support when it is about their own health ${ }^{(36)}$.

Unfortunately, if measures are not taken in favor of nursing workers, no symbolic tribute will be able to safeguard the lives of these workers, reduce deaths among professionals in the category or restore lost lives, while acting on behalf of society.

\section{Study limitations}

This study has a temporal limitation, as the publications were collected considering only the period from May 12 to 20, 2020. Furthermore, there is the fact that the publications were collected on a single site and it is also worth considering that the health crisis is still ongoing, therefore, until it is normalized, new data will emerge and may lead to differentiated discussions.

\section{Contributions to nursing}

The use of IRAMUTEQ ${ }^{\circ}$, in addition to limiting subjectivity bias, increases scientific rigor, since it employs statistical tests that are applied to qualitative data. In this case, arising from news from Cofen during the Nursing Week 2020, showing that the profession was in mourning for the more than 100 professionals in the category killed in the fight against the pandemic, which strengthens and reaffirms the need to face better working conditions.

It is recommended to deepen and expand studies on the illness and death of nursing workers involved in the fight against COVID-19, as well as carrying out other narrative and documentary research that can help to contextualize the history of the pandemic, which represents, so far, the biggest pandemic of the $21^{\text {st }}$ century.

\section{FINAL CONSIDERATIONS}

During the Nursing Week 2020, the themes published by Cofen and circulating on social networks and media pointed to the grief experienced by the category due to the death of its members and the need to face the category for better working conditions.

The results also show that, in order to overcome the current health crisis, it is necessary to recognize science and SUS, the valuation and protection of nursing workers' physical and mental health, as well as the fight against fake news and misinformation. Such strategies will make it possible to face the contradictions and misunderstandings that Brazilian nursing experience, allowing the qualitative transformation of the profession to occur.

\section{REFERENCES}

1. Associação Brasileira de Enfermagem. Diretrizes para realização da 81a semana brasileira de enfermagem [Internet]. Brasília, DF: ABEn; 2020[cited 2020 Jun 01]. Available from: http://www.abennacional.org.br/site/wp-content/uploads/2020/04/Diretrizes_81SBEn-2020_26_04.pdf

2. Organização Pan-Americana da Saúde. Folha informativa: covid-19 [Internet]. [Genebra]: OPAS; 2020 [cited 2020 Jun 04]. Available from: https://www.paho.org/bra/index.php?option=com_content\&view=article\&id=6101:covid19\&ltemid=875

3. Costa NR, Jatobá A, Bella H, Carvalho PVR. As medidas de enfrentamento à pandemia da covid-19 no Brasil na percepção da população atuante nas mídias sociais [Internet]. [Rio de Janeiro]: Fiocruz; 2020[cited 2020 Jun 01]. Available from: http://www.cee.fiocruz.br/sites/ default/files/Relat\%C3\%B3rio\%20Pesq\%20percep\%20Covid-19_CEE_Vers\%C3\%A30\%20FINAL_15_04_2020.pdf

4. Oliveira AC, Lucas TC, Iquiapaza RA. What has the covid-19 pandemic taught us about adopting preventive measures?. Texto Contexto Enferm. 2020;29:e20200106. https://doi.org/10.1590/1980-265X-TCE-2020-0106

5. Organização Pan-Americana da Saúde. OMS define 2020 como ano internacional dos profissionais de enfermagem e obstetrícia [Internet]. Brasília, DF: OPAS; 2020[cited 2020 Jun 04]. Available from: https://www.paho.org/pt/ noticias/3-1-2020-oms-define-2020-como-ano-internacional-dos-profissionais-enfermagem-e-obstetricia

6. Conselho Federal de Enfermagem. Enfermagem realiza ato histórico em homenagem aos mortos pela covid-19 [Internet]. Brasília, DF: COFEN; 2020[cited 2020 Jun 08]. Available from: http://www.cofen.gov.br/enfermagem-realiza-ato-historico-em-homenagem-aos-mortospela-covid-19_79806.html

7. Conselho Federal de Enfermagem. Brasil tem 108 enfermeiros mortos e mais de 4,1 mil contaminados pelo coronavírus [Internet]. Brasília, DF: COFEN; 2020[cited 2020 Jun 08]. Available from: http://www.cofen.gov.br/brasil-tem-108-enfermeiros-mortos-e-mais-de-41-milcontaminados-pelo-coronavirus_79784.html

8. Conselho Federal de Enfermagem. Brasil representa um terço das mortes de profissionais de Enfermagem por Covid-19 [Internet]. Brasília, DF: COFEN; 2020[cited 2021 Jan 06]. Available from: http://www.cofen.gov.br/brasil-responde-por-um-terco-das-mortes-de-profissionaisde-enfermagem-por-covid-19_84357.html

9. Conselho Federal de Enfermagem. Observatório da Enfermagem [Internet]. Brasília, DF: COFEN; 2020[cited 2021 Feb 10]. Available from: http://observatoriodaenfermagem.cofen.gov.br/

10. Tong A, Sainsbury P, Craig J. Consolidated criteria for reporting qualitative research (COREQ): a 32-item checklist for interviews and focus groups. Int J Qual Health Care. 2007;19(6):349-57. https://doi.org/10.1093/intqhc/mzm042

11. Buus N, Perron A. The quality of quality criteria: replicating the development of the consolidated criteria for reporting qualitative research (COREQ). Int J Nurs Stud. 2020;102:103452. https://doi.org/10.1016/j.jinurstu.2019.103452 
COVID-19 pandemic and nursing week: analysis from software IRAMUTEQ Soares SSS, Souza NVDO, Carvalho EC, Queiroz ABA, Costa CCP, Souto JSS

12. Lima LMN, Andrade SR, Ruoff AB, Albuquerque GL. Decisões dos Conselhos de Enfermagem no Brasil: uma pesquisa documental. Enferm Foco. 2017;8(4):42-8. https://doi.org/10.21675/2357-707X.2017.v8.n4.1328

13. Amoras JAB, Sales APS, Sampaio ATL, Machado RM, Duarte SJH. Historical and dialectical materialism in nursing care: integrative review. J Nurs UFPE. 2016;10(4):1307-14. https://doi.org/10.5205/reuol.8464-74011-1-SM.1004201619

14. Loubère L, Ratinaud P. Documentation IRaMuTeQ 0.6 alpha 3 version 0.1 [Internet]. Toulouse, France: IRaMuTeQ; 2014 [cited 2020 Jun 01]. Available from: http://iramuteq.org/documentation/fichiers/documentation_19_02_2014.pdf

15. Camargo BV, Justo AM. Tutorial para uso do software [de análise textual] IRAMUTEQ [Internet]. Florianópolis (SC): UFSC; 2018 [cited 2020 Jun 06]. Available from: http://www.iramuteq.org/documentation/fichiers/tutoriel-portugais-22-11-2018

16. Conselho Federal de Enfermagem. Cofen adere a carta dos profissionais de saúde contra fake news [Internet]. Brasília, DF: COFEN; 2020 [cited 2020 Jun 04]. Available from: http://www.cofen.gov.br/cofen-adere-a-carta-dos-profissionais-de-saude-contra-fakenews_79772.html

17. Conselho Federal de Enfermagem. 'Perdi as contas de quantos corpos empacotei', relata técnica de Enfermagem [Internet]. Brasília, DF: COFEN; 2020[cited 2020 May 15]. Available from: http://www.cofen.gov.br/perdi-as-contas-de-quantos-corpos-empacotei-relata-tecnicade-enfermagem_79890.html

18. Conselho Federal de Enfermagem. 'Há um mês não vejo minha filha': longas jornadas, baixos salários e solidão [Internet]. Brasília, DF: COFEN; 2020[cited 202005 Jun]. Available from: http://www.cofen.gov.br/ha-um-mes-nao-vejo-minha-filha-longas-jornadas-baixossalarios-e-solidao_79927.html

19. Conselho Federal de Enfermagem. É hora de cuidar do essencial [Internet]. Brasília, DF: COFEN; 2020[cited 2020 Jun 05]. Available from: http://www.cofen.gov.br/e-hora-de-cuidar-do-essencial_80011.html

20. Conselho Federal de Enfermagem. Enfermeiros, técnicos e auxiliares de enfermagem merecem respeito [Internet]. Brasília, DF: COFEN; 2020[cited 2020 Jun 05]. Available from: http://www.cofen.gov.br/enfermeiros-tecnicos-e-auxiliares-de-enfermagem-merecemrespeito_80040.html

21. Conselho Federal de Enfermagem. Por que hospitais do RJ têm mais mortes de enfermeiros no País [Internet]. Brasília, DF: COFEN; 2020[cited 2020 Jun 05]. Available from: http://www.cofen.gov.br/por-que-hospitais-do-rj-tem-mais-mortes-de-enfermeiros-nopais-2_79895.html

22. Conselho Federal de Enfermagem. Profissionais merecem valorização e proteção em meio à COVID-19 [Internet]. Brasília, DF: COFEN; 2020[cited 2020 Jun 05]. Available from: http://www.cofen.gov.br/profissionais-merecem-valorizacao-e-protecao-em-meio-acovid-19_79739.html

23. Conselho Federal de Enfermagem. Canais de fake news têm mais alcance que os oficiais sobre covid-19 [Internet]. Brasília, DF: COFEN; 2020 [cited 2020 Jun 05]. Available from: http://www.cofen.gov.br/canais-de-fake-news-tem-mais-alcance-que-os-oficiais-sobrecovid-19_80039.html

24. Conselho Federal de Enfermagem. Contra mentiras, profissionais de saúde cobram ação das gigantes da tecnologia [Internet]. Brasília, DF: COFEN; 2020 [cited 2020 Jun 05]. Available from: http://www.cofen.gov.br/contra-mentiras-profissionais-de-saude-cobram-acao-dasgigantes-da-tecnologia_79789.html

25. Conselho Federal de Enfermagem. Enfermeira recuperada da covid-19 em Rondônia se torna exemplo de superação [Internet]. Brasília, DF: COFEN; 2020 [cited 2020 Jun 05]. Available from: http://www.cofen.gov.br/enfermeira-recuperada-da-covid-19-em-rondonia-se-tornaexemplo-de-superacao_79907.html

26. Conselho Federal de Enfermagem. Presidente da Fiocruz ressalta importância da ciência no combate à covid-19 [Internet]. Brasília, DF: COFEN; 2020[cited 2020 Jun 05]. Available from: http://www.cofen.gov.br/presidente-da-fiocruz-ressalta-importancia-da-ciencia-nocombate-a-covid-19 79837.html

27. Conselho Federal de Enfermagem. Justiça concede testagem a profissionais de enfermagem sintomáticos em Sergipe [Internet]. Brasília, DF: COFEN; 2020[cited 2020 Jun 05]. Available from: http://www.cofen.gov.br/justica-concede-testagem-a-profissionais-de-enfermagemsintomaticos-em-sergipe_79956.html

28. Conselho Federal de Enfermagem. Cofen repudia discriminação a profissionais de enfermagem no Rio [Internet]. Brasília, DF: COFEN; 2020[cited 2020 Jun 05]. Available from: http://www.cofen.gov.br/cofen-repudia-discriminacao-a-profissionais-de-enfermagem-norio_79876.html

29. Organização Pan-Americana da Saúde. Entenda a infodemia e a desinformação na luta contra a covid-19: kit de ferramentas de transformação digita: ferramentas de conhecimento [Internet]. [Brasília, DF]: OPAS; 2020[cited 2020 Jun 04]. Available from: https://iris.paho. org/bitstream/handle/10665.2/52054/Factsheet-Infodemic_por.pdf?sequence =5

30. Oliveira WKD, Duarte E, França GVA, Garcia LP. How Brazil can hold back covid-19. Epidemiol Serv Saude. 2020;29(2):e2020044. https://doi. org/10.5123/S1679-49742020000200023

31. Rafael RMR, Neto M, Carvalho MMB, David HMSL, Acioli S, Faria MGA. Epidemiology, public policies and Covid-19 pandemics in Brazil: what can we expect?. Rev Enferm UERJ. 2020;28:e49570. https://doi.org/10.12957/reuerj.2020.49570

32. Soares SSS, Passinho RS, Belasco IC, Silva HPL, Mendes FCP, Carvalho EC, et al. Cloroquina e covid-19: reflexões à luz da ética, bioética e ciência. In: Soares SSS, Souza NVDO, Carvalho EC, Farias SNP, organizadoras. O complexo mundo do trabalho em saúde e as implicações para enfermagem. Belo Horizonte: Synapse Editora; 2021. p. 27-34. https://doi.org/10.36599/editpa-2021_cmp0003 
COVID-19 pandemic and nursing week: analysis from software IRAMUTEQ Soares SSS, Souza NVDO, Carvalho EC, Queiroz ABA, Costa CCP, Souto JSS

33. Conselho Federal de Enfermagem. Enfermeira comove internautas com relato sobre trabalho em meio ao coronavírus [Internet]. Brasília, DF: COFEN; 2020[cited 2020 Jun 01]. Available from: http://www.cofen.gov.br/enfermeira-comove-internautas-com-relato-sobre-trabalhoem-meio-ao-coronavirus_77790.html

34. Conselho Federal de Enfermagem. Enfermagem em números [Internet]. Brasília, DF: COFEN; 2020[cited 2020 Jun 03]. Available from: http:// www.cofen.gov.br/enfermagem-em-numeros

35. Oliveira KKD, Freitas RJM, Araújo JL, Gomes JGN. Nursing now e o papel da enfermagem no contexto da pandemia e do trabalho atual. Rev Gaucha Enferm. 2021;42(spe):e20200120. https://doi.org/10.1590/1983-1447.2021.20200120

36. Machado MH, coordenadora. Perfil da enfermagem no Brasil: relatório final [Internet]. Rio de Janeiro: Fiocruz; 2015 [cited 2020 Jun 03]. (Pesquisa perfil da enfermagem no Brasil; v. 1). Available from: http://www.cofen.gov.br/perfilenfermagem/pdfs/relatoriofinal.pdf

37. World Health Organization. State of the world's nursing 2020 [Internet]. [Geneva]: WHO; 2020[cited 2020 Jun 09]. Available from: https:// www.who.int/publications/i/item/nursing-report-2020

38. Laitano ADC, Silva GT, Almeida DB, Santos VP, Brandão MF, Carvalho AG, et al. Precariousness of the work of the nurse: professional militancy from the perspective of the press. Acta Paul Enferm. 2019;32(3):305-11. https://doi.org/10.1590/1982-0194201900042

39. Marx K. O capital. São Paulo: Nova Cultural; 1996. (Os Economistas; livro I, tomo 2).

40. Antunes R. O privilégio da servidão: o novo proletariado de serviços na era digital. São Paulo: Boitempo; 2018.

41. Leal JAL, Melo CMM. The nurses' work process in different countries: an integrative review. Rev Bras Enferm. 2018;71(2):413-23. https://doi. org/10.1590/0034-7167-2016-0468

42. Dutra HS. Social division of work and nursing. J Nurs UFPE. 2016;10(11):4161-3. https://doi.org/10.5205/ reuol.9881-87554-1-EDSM1011201643

43. Silva RM, Vieira LJES, Garcia Filho C, Bezerra IC, Cavalcante AN, Netto FCB, et al. Labor market insecurity for nursing assistants and technicians in the State of Ceará, Brazil. Cienc Saude Colet. 2019;25(1):135-45. https://doi.org/10.1590/1413-81232020251.28902019

44. Abadía C, Pinilla MY, Ariza K, Ruíz HC. Neoliberalismo en salud: la tortura de trabajadoras y trabajadores del instituto materno infantil de Bogotá. Rev Salud Publica [Internet]. 2012[cited 2021 Feb 06];14(supp 1):18-31. Available from: http://www.scielo.org.co/pdf/rsap/v14s1/v14s1a03.pdf

45. Souza NVDO, Gonçalves FGA, Pires AS, David HMSL. Neoliberalist influences on nursing hospital work process and organization. Rev Bras Enferm. 2017;70(5):912-9. https://doi.org/10.1590/0034-7167-2016-0092.

46. Organização Pan-Americana da Saúde. Em meio à pandemia de covid-19, novo relatório da OMS pede investimento urgente em profissionais de enfermagem [Internet]. Brasília, DF: OPAS; 2020[cited 2020 Jun 03]. Available from: https://www.paho.org/bra/index. php?option=com_content\&view=article\&id=6139:em-meio-a-pandemia-de-covid-19-novo-relatorio-da-oms-pede-investimento-urgenteem-profissionais-de-enfermagem\&ltemid $=812$

47. Rossi P, Dweck E. Impacts of the new fiscal regime on health and education. Cad Saude Publica. 2016;32(12):e00194316. https://doi. org/10.1590/0102-311X00194316

48. Oliveira AC. Desafios da enfermagem frente ao enfrentamento da pandemia da covid-19. REME. 2020;24:e-1302. https://doi. org/10.5935/1415-2762.20200032

49. Defensoria Pública do Estado do Rio de Janeiro. DPRJ constata déficit de mais de mil leitos em hospitais da capital [Internet]. 2020 [cited 2020 Jun 03]. Available from: http://www.defensoria.rj.def.br/noticia/detalhes/9195-DPRJ-constata-deficit-de-mais-de-mil-leitos-em-hospitais-da-capital

50. Soares SSS, Souza NVDO, Silva KG, César MP, Souto JSS, Leite JCRAP. Covid-19 pandemic and rational use of personal protective equipment. Rev Enferm UERJ. 2020;28:e50360. https://doi.org/10.12957/reuerj.2020.50360

51. Werneck GL, Carvalho MS. The COVID-19 pandemic in Brazil: chronicle of a health crisis foretold. Cad Saude Publica. 2020;36(5):e00068820. https://doi.org/10.1590/0102-311x00068820

52. Lemos Jr EP, Brugnara AF. O princípio da dignidade da pessoa humana no ordenamento jurídico brasileiro. Rev Faculdade Direito UERJ. 2017;(31):86-126. https://doi.org/10.12957/rfd.2017.26639

53. Hone T, Mirelman AJ, Rasella D, Paes-Sousa R, Barreto ML, Rocha R, et al. Effect of economic recession and impact of health and social protection expenditures on adult mortality: a longitudinal analysis of 5565 Brazilian municipalities. Lancet Glob Health. 2019;7:e1575-83. https://doi.org/10.1016/S2214-109X(19)30409-7

54. Amaral TC. Direito à saúde: dilemas do fenômeno da judicialização da saúde. Cad Ibero-Amer Dir Sanit. 2019;8(2):123-32. https://doi. org/10.17566/ciads.v8i2.530

55. Paixão ALSD. Reflections on the judicialization of the right to health and its implications in the SUS. Cienc Saude Colet. 2019;24(6):2167-72. https://doi.org/10.1590/1413-81232018246.08212019

56. Congresso Federal (BR). Constituição da República Federativa do Brasil [Internet]. Brasília, DF: 2020 [cited 2020 Jun 03]. Available from: http://www.planalto.gov.br/ccivil_03/constituicao/constituicao.htm 